\title{
Knowledge Transfer and Innovation in Brazilian Multinational Companies
}

\author{
Alisson Eduardo Maehler', Carla Maria Marques Curado², Eugênio Ávila Pedrozo³, José Pedro Pires ${ }^{4}$
}

\begin{abstract}
The article analyzes how innovation generation occurs in subsidiaries of Brazilian multinational corporations acting in Portugal, specifically the role of customers in the process and the knowledge dynamics. A multiple case study approach was conducted in four subsidiaries operating in the Portuguese market for at least one year. Firms came from different activity sectors and sizes. Results identify permanent knowledge exchange flows between subsidiaries and headquarters, while the largest pour is from the later ones (in Brazil) to their wings in Portugal. There are frequent innovations taking place in Portuguese subsidiaries. Such innovation processes are typically incremental in nature and occur predominantly in only some areas of the organization, where greater specialization and expertise are located. The most relevant results regard the existing strong interaction between subsidiaries and markets, especially with the larger customers that contribute with suggestions and are able to influence the new products creation in the subsidiaries.
\end{abstract}

Keywords: : Knowledge; innovation; customer intelligence; multinational companies; subsidiaries.

'M.Sc., Assistant Professor, Federal University of Pelotas, Pelotas, Brazil and PhD. candidate at Federal University of Rio Grande do Sul, Porto Alegre, Brazil.Washington Luiz Street, 855, zip code: 90.010-000, Centro - Porto Alegre- RS - Brazil. E-mail: aemaehler@ea.ufrgs.br Telephone number: +55 533222798 I

${ }^{2}$ PhD., Full Professor at ISEG - School of Economics and Management, Technical University of Lisbon, Lisbon, Portugal. Miguel Lupi Street, 20, zip code: I 249-078, Lisbon, Portugal. E-mail: ccurado@iseg.utl.pt

${ }^{3}$ PhD., Full Professor, Management School, Federal University of Rio Grande do Sul, Porto Alegre, Brazil. Washington Luiz Street, 855

Porto Alegre, RS, zip code: 90.010-000. E-mail: eapedrozo@ea.ufrgs.br

${ }^{4}$ M.Sc. School of Business and Economics, Maastricht University, The Netherlands. Tongersestraat 53, 62II LM Maastricht, The

Netherlands. P.O. Box 616, 6200 MD Maastricht,The Netherlands. E-mail:j.barretogamitopires@student.maastrichtuniversity.nl 


\section{Introduction}

In the Brazilian context, there was a recently sharp rise in the development of MNCs and the consequent investment overseas (Fleury \& Fleury, 2007). Brazilian MNCs perform activities in many different economic sectors and assume very different sizes. Although much of their investments are allocated especially in Latin America, the European market has absorbed large amounts of investment. More recently, in the Portuguese market there has been a considerable increase in both the number of Brazilian MNCs installed in its territory and in the amounts of capital invested. Entrepreneurs and executives identify the short cultural distance, language proximity and the ease of access to the European Community as the major reasons for outward FDI in Portugal (Costa, 2006). Brazilian MNCs seek access to capital, human and technological resources which are often scarce in Brazil (Guillen \& Garcia-Canal, 2009). Knowledge also becomes a sought after resource, for being an increasingly important asset for organizations (Gray, 2006, Yang et al., 2008).

Innovation, flexibility and continued growth of operations have become imperatives in business strategy (Jantunen, 2005; Easterby-Smith \& Prieto, 2008). New products, new processes and new markets are drivers for growth and development of businesses, regardless of activity sector, geographical region or firm size. Thus, knowledge has become one of the most important assets for organizations (Hsu and Wang, 2008). MNC's units located in different countries open the possibility of exchange and access to new knowledge and information, which seems to be essential in highly competitive environments. Internationalization strategies can be directed towards the pursuit of knowledge and innovation that may be limited in the firm's home country (Camuffo et al., 2007).

Accordingto VernonandWells(I99I) technologicaladvantage is an important component of the internationalization of the firm, since it allows overcoming its rivals in the domestic market and exploiting less developed markets. In addition, companies from technologically advanced sectors can choose to create subsidiaries, through mergers or acquisitions, in industrialized and technologically advanced countries, taking advantage of local know-how. Such aspect can be observed in Fors (1998), who noted that Swedish MNC's tend to invest in countries with mature and advanced technology. The process of accessing new knowledge and generating innovation takes place not only internally in the firm, using a research and development (R\&D) laboratory or investments in science and technology, but also by means of interaction with customers, suppliers and even competitors. Business specificities and market contingencies can lead to a wealth of useful insights to the development of new products. In this sense, monitoring the environment, particularly customers, suppliers and competitors, is a practice increasingly adopted by companies.

The set of formal means to obtain information about competitors is known as competitive intelligence (Wheelen \& Hunger, 2008), but much information on competitors is obtained through informal means, from workers, suppliers and customers, in publications and industry conferences, or even using the internet. Competitive intelligence is a common practice in the business world. Authors such as Porter (2008) have highlighted the issue of monitoring competitors and analyzing their strategies. The low costs involved and the immediate results seem to be motivating factors in such practice, because once the movement of a competitor is perceived, actions to neutralize it may soon be taken.

In recent years, customers have become an important source of information, due to increasing competition, power of choice and available information (Thomke \& Hippel, 2002). The marketing literature points to the existence of practices in which the customer is increasingly being asked to provide opinions and information, based on focus groups, case studies, customer advice or large surveys that attempt to measure the perception and buying behaviors. However, when information is obtained from customers, there is no agreed-upon definition. Therefore, the present paper proposes customer intelligence to refer to the phenomenon.

The internationalization of Brazilian MNCs is a recent phenomenon (Fleury \& Fleury, 2007). Relationships between customers and the generation of innovations in subsidiaries of Brazilian MNCs abroad has been little explored in literature so far. Even the number of studies addressing such subsidiaries is very limited (Oliveira Jr., 2007), since many authors have opted to study the parent companies of these MNCs. The present study was developed to understand how the processes of generating innovations in subsidiaries contributes to the dynamics of knowledge and, subsequently to value creation in highly 
dynamic sectors of the economy which are responsible for generating wealth and employment that help sustain the growth of developing countries. The main purpose of the study is to examine how does innovation generation occurs in the subsidiaries of Brazilian MNCs operating in Europe, particularly in the Portuguese market. The paper is both needed and relevant by answering the following research questions: how does the generation of innovations in subsidiaries occurs in Brazilian MNC's abroad? What is the role of customers in the process?

Thus, previous studies have focused only at the headquarters of Brazilian companies, such as Oliveira Jr. (2007), Ribeiro e Oliveira Jr. (2009), Sherer et al. (2009), or companies from developed countries with units located abroad, such in Fors (1998). The present research, in this way, is intended to enlightening the understanding of an emergent phenomenon, not yet fully understood, which is the behavior of Brazilian MNCs abroad (Fleury \& Fleury, 2007).

\section{Knowledge and innovation}

Numerous authors consider the organizational knowledge as one of the most important resources of the firm (Peteraf, 1993; Hsu \& Wang, 2008). Although its importance is emphasized at the theoretical level, empirical studies rarely discuss or even formulate questions and propositions on knowledge being such a critical resource, demanding further developments. However, the knowledge, especially the tacit one, which resides in the minds of individuals or inside organizations (Daft \& Weick, 1984), is unique and specific to each firm. A series of circumstances, such as the location in which it is embedded, the time of existence, organizational structure, diversity of staff, strategic choices, among other factors, lead to a unique composition of data and information. All these elements, along with the interactions between individuals or even each one of these individually, are transformed into knowledge. As a result, innovations can be created, new inter-organizational arrangements can be established, new decisions can be taken and new strategies can be formulated.

The only true lasting competitive advantage is knowledge (Nonaka, 1991). Identifying, developing and turning knowledge into valuable products and services becomes a set of strategic activities for the firm (Cohen \& Levinthal, 1990). The Knowledge-based view of the firm is a recent extension of the Resource-based view of the firm very adequate to the present economic context (Curado, 2006). Non-observable factors have impact on firm performance. Those factors, such as management capabilities and competences, technical knowledge or tacit organizational routines, may turn out to be the main determinants of firm performance (Dess et al., 1995). The access to scientific and technological knowledge as well as the ability to apprehend, accumulate and use it defines the degree of competitiveness of firms (Wang \& Ahmed, 2007). Nevertheless, knowledge alone is not enough. Firms have to find ways to transform knowledge into new products, processes and organizational modes, that is, innovation outputs.

The ability of the firm to absorb knowledge, accumulate it and turn it into innovations is known as absorptive capacity. The concept has gained considerable attention since the work of Cohen and Levinthal (1990) and it has been used to analyze the processes of knowledge transfer and innovation in a variety of contexts, such as clusters, alliances, MNCs and patent studies. According to it, the more a firm already knows, the more it can learn (Cohen \& Levinthal, 1990). Enterprises with a good base of existing knowledge (such as highly skilled and trained workforce), combined with considerable investments in R\&D have greater absorptive capacity (McCann \& Folta, 2008). Accordingly, MNCs with high absorptive capacity should have a better chance of benefiting from knowledge dispersed in the general environment, through information obtained from suppliers or customers.

The result of absorptive capacity - innovation - is a broad and multifaceted term. Bessant \& Tidd (2007) dismember the general concept of innovation in four dimensions of change in what they call the "4P's of innovation: product, process, position and paradigm. Product innovation is a change in the products / services themselves, while process innovation refers to changes in the ways they are created and distributed. With regards to position innovation, it occurs when there is a change in the context in which the products / services are introduced. Finally, paradigm innovation involves changes in the underlying mental models adopted by the company. 


\section{I.I Innovations in MNC's}

Knowledge is seen as one of the foundations of innovation creation and, consequently, generates superior competitive advantages over competitors. Customers seem to play an important role in generating ideas and useful knowledge to the innovation process. By monitoring the environment and searching for information from customers who can generate new insights or suggest new applications for existing products, firms can create new products and services.

In the process of generating innovation, information obtained from the environment (environmental scanning) plays an important role because it can play a complementary role to existing data and information within the firm. Daft and Weick (1984) offer an analytical model, similar to an open system approach, presenting the relevancy of scanning the environment, interpreting collected data and giving it some meaning. The proposed result of such sequence (system's output) would be learning and consequent action taking.

In the perspective of Daft \& Weick (1984), organizations themselves are understood as systems of interpretation (as they read the world). The process is determined by both the managers' beliefs about the environment where they are based and the embeddeness of companies in the business environment. The way managers perceive the environment (and, consequently, how the organization interprets it) leads to the establishment of different strategies and action measures. Moreover, the learning arising from the process may play an important role in the acquisition and accumulation of knowledge, enabling it to generate innovations more or less tailored to its business and its customers.

Competitive analysis it is essential to delineate the strategies to pursue in the markets especially in the case of the subsidiaries that have recently started operations in a market so far and little known. MNC have to overcome the disadvantage of being foreigners in new markets. However, it is difficult to achieve the knowledge levels competitors operating for long on the markets already have (e.g. the experience curve associated). The quest for market adaptation, innovation and the introduction of better products are essential tasks. After all, in any industry innovation becomes the engine of business competitiveness and a major differentiation element over competition.
Traditionally, suppliers were primarily responsible for product development (Thomke \& Hippel, 2002). However, new approaches such as customers-as-innovators, gives the customer more responsibilities in the creation of new products. According to Thomke and Hippel, 2002, the activities of design and prototyping are carried out by customers. The time and cost savings are substantial for the company, since the customer interactions are reduced and the production process is accelerated and proves to be more effective. In addition, customers benefit from a product tailored to their needs in a shorter period of time.

It is common practice in some companies to engage customers in the development of their products. These customers, so called lead users are ahead of market trends and have needs that go beyond those of an average customer (Wheelen \& Hunger, 2008). The goal of including ideas from customers in new products development is not only to respect their needs but also aiming to the subsequent acceptance of products in the market, which tends to be more effective when customers themselves participate in the process.

\section{Research Method}

The four MNC involved in the research were chosen for the multiple-case study for being Brazilian corporations having subsidiaries acting in Portugal for over one year. The four corporations came from different industries, two from manufacturing sectors and two from the services industries. The companies were chosen considering their size and performance levels in the Portuguese market. Companies' names were kept secret, as requested by their representatives, being their original names replaced by $A, B, C$ and $D$.

Recently, in the area of international management there has been an increase in the amount of publications that use qualitative approaches, especially the case study method, Delphi and focus groups. In this sense, Li and Hsieh (2009) emphasize the need for more in-depth case studies in the analysis of knowledge transfer in MNCs, which use triangulation of data techniques (crossing multiple information sources). 


\section{I Cases' description}

Company A is currently the largest Latin American manufacturer of electrical engines and one of the largest worldwide. Company A operates in several different manufacturing processes from control and protection, speed variation, industrial process automation, power generation and distribution, and industrial paints. (Company A, 2010). The production is concentrated in eight manufacturing facilities located in Brazil, three in Argentina, two in Mexico, one in China and one in Portugal, in the city of Oporto (Subsidiary A, 2010).

The second case addresses Company B. The company is the largest bank in Brazil and one of the largest banks in Latin America (Subsidiary B, 2008). The bank remains one of the largest in several markets, especially with regard to the agribusiness, corporate businesses, retail and recently also in the real estate sector, given its huge fresh growth in Brazil. With regard to the personnel structure, the total number of employees is 103,923 (March 2010), and the bank also coordinates 10,019 trainees working throughout the country (Company B, 20I0). For being a public company all employees are admitted through public tender.

The third case is Company C, headquartered in Sao Paulo - SP. It provides services to corporate customers on automation of administrative and financial processes using software. The company was founded 28 years ago and its presence in Europe dates back 2003, serving mainly the financial and insurance sectors. Company C's subsidiary in Lisbon has two managing partners and six employees in the human resources, IT and operations departments. Foreign markets are served through alliances with local companies and through vendors / consultants who distribute both proprietary software and other brands. In general solutions are customized to each customer and attend to the specific needs of each one. According to the head of the Portuguese unit, it is a way to generate new knowledge and innovations.

Finally, Company $D$ is one of the largest aviation companies in the world, particularly in the medium sized aviation market. The aviation market is divided in three distinct categories: commercial, military and business. Each category requires specific models and developments. Since its founding, in the 1960's, the company has manufactured approximately five thousand aircrafts operating in 88 countries spread over the five continents (Company D,
20II). MNC D subsidiary in Portugal is not a fully owned subsidiary, since its control is held by a joint venture between a Brazilian company, a European consortium and the Portuguese State (Subsidiary D, 2010). The company in Portugal does not produce aircrafts in full, but only some parts (in general, design-to-build components) and has maintenance services.

\subsection{Data collection and analysis}

The study conducted a multi-case study involving four MNCs and their Portuguese subsidiaries. Generally, studies in the field of international management have prioritized analysis of American and European multinationals with units in developed countries. We wanted to do the opposite, opening a new research perspective. Thus, data was obtained from primary sources (semi-structured interviews with executives and in situ observations) and through secondary sources, especially archival research. Three experts were validate the data collection instrument (interview guide) and proposed minor changes to the original instrument, which was based especially in the works of Chini (2004), Riege (2007), Li and Hsieh (2009) and Hong and Nguyen (2009).

The interviewees were chosen based upon their senior management posts and different areas of business (IT, HR or Sales). The snow-ball method was used, where managers interviewed indicate the next one, thus facilitating contacts. More than one person per company was interviewed, so as to fill a gap highlighted by Yang et al. (2008), in which international management research often interviews only one individual by organization. Table I provides details on the interviewees. 


\begin{tabular}{|c|c|c|c|c|}
\hline Company & Intervieweec̃ Post & Intervieweec̃ E ducation & $\begin{array}{l}\text { Interviewee } \bar{s} \\
\text { Seniority at the } \\
\text { Company }\end{array}$ & $\begin{array}{c}\text { Intervieweé, } \\
\text { International } \\
\text { Experience }\end{array}$ \\
\hline \multirow[b]{3}{*}{ Company A } & Engineering manager & Electric engineering & 12 years & None \\
\hline & HR manager & Economy & 9 years & None \\
\hline & Sales manager & $\begin{array}{c}\text { M echanical } \\
\text { engineering/M BA in } \\
\text { management }\end{array}$ & 6 years & Portugal (4 years) \\
\hline \multirow{4}{*}{ Company B } & HR manager; & $\begin{array}{l}\text { M anagement/M BA in } \\
\text { finance }\end{array}$ & 22 years & Spain (5 years) \\
\hline & Sales manager & System analysis & 26 years & Portugal (3 years) \\
\hline & IT Supervisor & Thecnical course & 37 years & $\begin{array}{c}\text { Portugal (10 } \\
\text { years) }\end{array}$ \\
\hline & A gency manager & M anagement & 7 years & Portugal (9 years) \\
\hline \multirow{3}{*}{ Company $\mathrm{C}$} & CEO in Brasil; & System analysis & 28 years & None \\
\hline & Sales manager & System analysis & 8 years & USA (6 months) \\
\hline & IT manager & Computer Science & 3 years & Brazil (6 months) \\
\hline \multirow{2}{*}{ Company D } & Sales director & $\begin{array}{c}\text { A eronautical engineering/ } \\
\text { M aster in aeronautical } \\
\text { engineering }\end{array}$ & 4 years & $\begin{array}{c}\text { Portugal (4 years) } \\
\text { England (1 year) }\end{array}$ \\
\hline & HR director & Sociology & 4,5 years & $\begin{array}{l}\text { Brazil (3 months) } \\
\text { A ngola (3 } \\
\text { months) }\end{array}$ \\
\hline
\end{tabular}

Table I: Interviewees' profile

Data analysis was performed using content analysis as described by Bardin (2009), according to which content analysis should be an objective, systematic and quantitative description of the content expressed by communication. Analytical categories were created for the classification of units and the communication was broken down according to predefined rules. Responses from all of the interviews were categorized by company and respondent respecting the interview guide. The categories are the ones described in Table 2.

\begin{tabular}{|l|l|l|}
\hline \multirow{5}{*}{ Innovation } & Category of analysis & Sub-categories \\
\cline { 2 - 3 } & $\begin{array}{l}\text { Generation of Innovation in } \\
\text { thegroup }\end{array}$ & $\begin{array}{l}\text { - There is innovation generation in HQ and S; } \\
\text { - There is innovation generation, but only in H } \\
\text { - There is innovation generation, but only in S; } \\
\text { - There is no innovation generation in the group. }\end{array}$ \\
\cline { 2 - 3 } & $\begin{array}{l}\text { Innovation generation } \\
\text { frequency }\end{array}$ & $\begin{array}{l}\text { a) The company introduces innovations frequently; } \\
\text { b) The company does not introduce innovations } \\
\text { frequently. }\end{array}$ \\
\cline { 2 - 3 } $\begin{array}{l}\text { Innovation generation } \\
\text { process }\end{array}$ & $\begin{array}{l}\text { a) By monitoring the environment } \\
\text { (competitors, customers and suppliers); } \\
\text { b) Through the R \& D department; } \\
\text { c) By means of strategic groups. }\end{array}$ \\
\hline
\end{tabular}

Table 2: Categories and sub-categories for content analysis 


\section{Results}

\section{I Generation of Innovation in the group}

The analysis of the cases indicates that the generation of innovation is concentrated in the headquarters, leaving to the subsidiaries to generate innovations in areas where it has specific expertise. Data analysis shows interesting results. Four dimensions were identified: a) The existence and role of innovation; b) The spotlight of innovation in some areas and not in the organization as a whole; c) The role of internationalization for innovation; d) The participation of subsidiaries in the generation of innovations, through a reverse flow of knowledge.

Regarding the first aspect, the existence and role of innovation, it stands out clearly in the statements of the executives interviewed. The four MNCs in the study, even though coming from different sectors (manufacturing and services) and sizes, innovation appears to be integrated in the overall strategy of both the $\mathrm{HQ}$ and its subsidiaries. Although managers interviewed were from different organizational departments, innovation strategy was constantly stressed.

On the second topic, innovation does not cover all areas of business, but focuses in certain products/processes. It applies to Company $A$, which is specialized in the development and production of blast-resistant motors. In turn, Company B IT manager emphasizes the high qualification of computer systems and information systems, which allows the multinational competitive advantage over competitors. Finally, Company $C$ is an expert in management systems, in particular Balanced Scorecard, and major changes in the system were originated in the Portuguese subsidiary, due to its intensive interactions with local customers.

As regards the third point, evidence collected supports that internationalization itself has contributed as a promoter for innovation. The case of Company B, in which the sales manager notes that "with internationalization (innovation) is more frequent" provides a clear sign that there is a connection between the two phenomena. The present result is consistent with one of the most known internationalization theories of MNCs, the Theory of Product Life Cycle, Vernon (1966), focuses its attention on technological development.
Finally, the last dimension discussed was the participation of subsidiaries in the generation of innovations, through reverse flows of knowledge, i.e. the growing importance of subsidiaries as a source of knowledge. Traditionally, literature on knowledge transfer supported that knowledge was originated in the $\mathrm{HQ}$, usually located in developed countries. The main arguments were the large volume of resources devoted to R\&D, high qualification of its human resources and high managerial expertise. However, in recent years several authors (Yang et al., 2008; Ribeiro \& Oliveira Jr., 2009) are showing the reverse knowledge flow, showing that this process is getting common and more intense, as could be seen in the cases that we have studied.

As subsidiaries gain international experience, they increase their competitiveness and acquire new skills, the new knowledge they create is transferred to the $\mathrm{HQ}$. So, the HQ absorbs the knowledge produce in its subsidiaries. As the words of the manager of Company $B$ indicate "there are also things that we (subsidiary) have here that we transfer to them (HQ)." (Subsidiary B Production Manager). The reverse flow feeds the process of absorptive capacity of knowledge.

Considering Company A example, as the subsidiary specializes in a product, like blast-resistant engines, the expertise is transferred to the HQ. Regarding Company $B$, as its Portuguese subsidiary augments its knowledge base of the Portuguese retail market, it transfers useful knowledge to the HQ strategy in Brazil, contributing to strategy formulation, especially in regard to market segmentation, consumer habits and financial transactions. The same was observed in Company $D$, in which competences in maintenance and aero-structures are transferred to the Brazilian units and $\mathrm{HQ}$. Therefore, these case studies provide additional evidence to assert that knowledge transfers exist from subsidiaries to their $\mathrm{HQ}$, which has also been recently identified by other authors (Ribeiro \& Oliveira Jr., 2009). Nevertheless, more case studies need to be addressed to add to cumulative knowledge on the subject. Table 3 summarizes and presents de frequency of texts in all interviews: 


\begin{tabular}{|c|c|c|}
\hline Category of analysis & Sub-categories & Frequency (texts) \\
\hline $\begin{array}{l}\text { Generation of } \\
\text { Innovation in thegroup }\end{array}$ & $\begin{array}{l}\text { - There is innovation generation in } \mathrm{HQ} \text { and } \mathrm{S} \text {; } \\
\text { - There is innovation generation, but only in } \mathrm{HQ} \text {; } \\
\text { - There is innovation generation, but only in } \mathrm{S} \text {; } \\
\text { - There is no innovation generation in the group. }\end{array}$ & $\begin{array}{l}17 \text { texts } \\
02 \text { texts } \\
0 \text { text } \\
01 \text { text }\end{array}$ \\
\hline $\begin{array}{l}\text { Innovation generation } \\
\text { frequency }\end{array}$ & $\begin{array}{l}\text { a) The company introduces innovations } \\
\text { frequently; } \\
\text { b) The company does not introduce } \\
\text { innovations frequently. }\end{array}$ & $\begin{array}{l}18 \text { texts } \\
01 \text { text }\end{array}$ \\
\hline $\begin{array}{l}\text { Innovation generation } \\
\text { process }\end{array}$ & $\begin{array}{l}\text { a) By monitoring the environment } \\
\text { (competitors, customers and suppliers); } \\
\text { b) Through the } R \& D \text { department; } \\
\text { c) By means of strategic groups. }\end{array}$ & $\begin{array}{l}24 \text { texts } \\
04 \text { texts } \\
04 \text { texts }\end{array}$ \\
\hline
\end{tabular}

Table 3: Text frequencies in the managers' interviews

\subsection{Innovation generation frequency}

From the interviews content analysis is clear that innovation is frequent, and occurs both in headquarters and subsidiaries (though to a lesser extent in the subsidiaries). The major research facilities such as laboratories and major partnerships with universities and research centers are concentrated in the headquarters (HQ) based in Brazil. There is little control of R\&D activities in the subsidiaries.

When asked if the company launches innovations frequently, there was unanimity in affirmative responses. It is possible that due to one of data collection methods was the interview, respondents gave a positive answer to the interviewer considering that would be the "correct" one. As emphasized by Barañano (2008) interviewees' responses tend to be "socially acceptable". The possible bias was controlled through documental analysis (in particular institutional folders and web sites). Interviews data triangulation with documents made it clear that the number of new products introduced recently, both by the $\mathrm{HQ}$ and by the subsidiaries supports the interviewees' responses.

In the view of one of the executives:

"Continuously, in the software area we operate, the technology area, this is a need (...). We do some major modifications and innovations, such as our simulations scenario in the software which we launched last April. For example, the quadrant analysis and forecast scenarios (...). That is the culture (of innovation) that I want to create in the company". (CEO of Company C, personal communication, September, 15, 2010).
The interviews content analysis originated two categories of responses, with regard to the frequency of innovation (see Table 2 and Table 3): a) the company is launching innovations frequently and b) the company is not releasing innovations frequently. Developing respondents' answers content analysis made categorization possible (categorical and frequency analysis was done, as described by Bardin, 2009).

\subsection{The process of generating innovation and the participation of customers}

A relevant issue of innovation generation remains to be the participation of customers and competitors. The four cases in the present study generated evidence on the adoption of customer intelligence strategies. As noted by Daft and Weick (1984), monitoring the environment proves to be an important tool for generating insights that otherwise would not be possible. The authors draw the attention to the role played by customers in the innovation process, which is a common trace among the MNCs in the present multiple case study.

The sales manager of Company B states that "we're looking outside the company at our market, and providing feedback to HQ." In addition, he also makes a similar observation, asserting that "it (the company) works on innovation that has its customers' participation in innovation". An interesting initiative to note is the Customers' Council, described by the same manager in which the top twenty customers of the company meet regularly to exchange 
information about their needs, fostering both radical innovations (originating solutions which do not yet exist) or incremental innovations (improvements on what already exists).

The issue of generating innovations through customer intelligence was better explored using the question "how is the process of generating innovation in the company and its subsidiaries?

The generation of innovations in subsidiaries occurs primarily through environmental scan. The results can be seen in Table 3. The representatives from four companies participating in the study were unanimous in relying in the market to generate innovations, according to their testimonies. Regarding the first category, environmental monitoring, it is quite visible in evidence from Company A when its production manager states that:

"Many times the identification of a new need happens in the external environment. Even a niche or an area with only a few players, or a customer with a specific need, like a special paint or other (...) When the process is approved, the project takes off, particularly in engineering it always needs support from a laboratory". (Production Manager of Company A, personal communication, August 10, 2010).

Company A HR manager notes that "in the end it is all about trying to respond to market demands. It is based on the perception of the customer and not the shortsighted vision of the scientist locked in the laboratory. It is very important to listen to the customer's needs."

At Company B it was also observed the involvement of customers. The sales manager of the company notes that "often the design of new products comes from the punctual demand of a customer visit." Furthermore, the interviewee added that there is an area of competitive intelligence, designed to monitor the market and bring new ideas into the organization.

Similarly, Company $\mathrm{C}$ also presents great customer participation in the generation of innovations. Its sales manager notes that:

"(Innovation) arises due to customer and market needs, through market trends and competitors' strategies analysis. So, a roadmap for what is to be developed is created and presented to customers at a later stage.
Knowledge is originated half inside and half outside the company. We have two related events, one is a Customers' Committee and the other is the Customers' Council in which we meet the top 20 and work together in each area to see what more can be done, or in a new way". (Commercial Manager of Company C, personal communication, September, 16, 2010).

Along the same line, Company C's CEO in Brazil states that "these things (ideas and innovations) arise (...) through interaction with customers because they expose their needs. Since customers interact with each other, then a lot of ideas generate, it is impressive." According to the CEO, innovation, particularly in the technological sector, is originated in external sources, as highlighted by Wheelen and Hunger (2008). Innovations are aimed at meeting market requirements and customer needs, as supported by Thomke and Hippel (2002).

Comparatively, the same phenomenon is observed in Company $D$ subsidiary (an aircraft manufacturer). The market director notes that there is no R\&D department in the subsidiary, but there is one engineering area which seeks to innovate. In addition, competition is constantly analyzed through practices of competitive intelligence. The relevant information gathered is then forwarded to the HQ in Brazil. Customers participate in the process in two ways: using the annual survey of customer satisfaction - through suggestions and complaints; and by means of communication channels, namely internet and customer service.

The participation of the R\&D department can be seen as a complementary activity, implementing and improving ideas and suggestions originated in the markets. It is plain clear in the words of the production manager at Company A, who states that after the idea (project) approval, it heads to the engineering department, which is supported by laboratories. Such process generates incremental innovations, in the sense that it introduces small product improvements and does not create new products challenging what previously existed in the market. The practice can lead to the generation of products that meet existing needs which are still unmet. The challenges firms face is to create products to meet needs that customers do not know they have yet, and what could be best achieved through radical innovations.

Finally, the MNCs in the study identified lead users, customers that are ahead of market trends and have 
needs that go beyond those of an average customer (Wheelen \& Hunger, 2008). The lead users identified are the largest customers, as the ones meeting in the Customers' Committee Company C. These customers are not compensated for their participation (which generally occurs every two months). However, they benefit from products tailored to their real needs by having a role in the development of the products they want and thus better understanding the product's performance than others in the market.

\section{Discussion and proposed model}

Some authors have been analyzing how innovation occurs in companies through the participation of customers. Urban and Hippel (1988) are among those who pioneered this research topic whose studies advanced to a more developed model (Thomke \& Hippel, 2002). The authors created a model focused on industrial companies in which customers participate in the design and prototyping of their desired products through the help of interactive tools which establish the connection customer-supplier. Other authors, such as Kelley and Littmann (200I) also highlight the role of customers in the innovation strategy. However, these studies neither focus exclusively in MNCs, nor in MNCs from developing countries.

Considering the literature there is so far no proposed model to address the role of customers in the innovation generation process that MNCs adopt. In order to respond to such challenge the present research was carried out, and a model of customer intelligence in subsidiaries is presented.

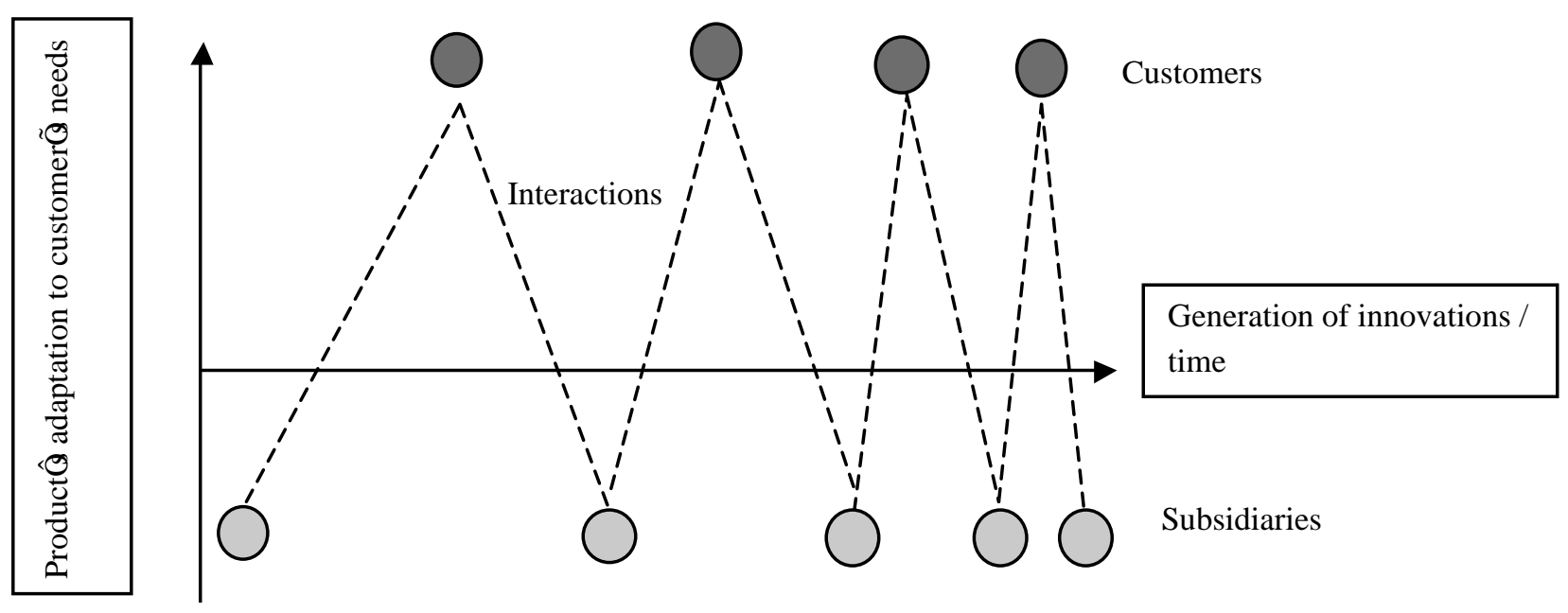

Figure 2: Customer intelligence contribution to innovation

In the above proposed model, the degree of adaptation to the end user is a function of time, based on repeated interactions customer-supplier. The greater the number of interactions and the longer the time elapsed, the more adapted the product becomes to customer needs. The generation of innovation takes the form of a saw tooth graphic with constant inflows and outflows of an idea, a prototype, tests and final results. The model considers the pre-existence of strong relationships between customers and suppliers in the benefit of innovation generation.
Subsidiaries learn and apply knowledge to the innovation generation by using the information gained in the interactions with the lead users. Of course not all ideas and information that is collected are used and transformed into products. In fact, only a small part is used. The greater challenge is to select relevant information, through the interpretation and generate useful learning. Having competitive intelligence practice experience and a large knowledge base developed through absorptive capacity (Cohen \& Levinthal, 1990) may be very helpful to address such challenge. 


\section{Conclusions, limitations and research gaps}

The present paper advances the understanding of how innovation generation occurs in subsidiaries of Brazilian MNCs operating in Portugal. There is a lack of studies addressing this specific issue, especially referring to the subsidiaries.

The paper proposes that an intense customer involvement in the generation of new ideas and useful insights is a relevant input to the innovative process. Moreover, the process allows the creation of products and services tailored to the market, with future guaranteed demand, and allowing for greater loyalty of users involved. The process can be very structured, for example by the means of using Customer's committees. In addition, findings from the present research project were reinforced by the diversity of managers from different areas within the organizations participating in the study and the triangulation of data preformed.

Using a multiple case studies revealed the existence have specific knowledge and expertise in some business areas of the subsidiaries, consistent with the subsidiary classification of "specialized contributing subsidiaries" from Birkinshaw and Morrison (1995). The total expertise and knowledge is sent to and concentrated at headquarters, despite those being located in a developing country - Brazil - in the present study.

Although the present paper adds important contributions on the subjects involved at exploratory level, the findings open up important research questions for future developments. For example, longitudinal studies that may examine innovation in the subsidiaries of Brazilian MNCs can contribute to identify whether the phenomenon is punctual or continuous over the years. It also opens up the discussion of the limitations of strategies modeled on incremental innovations that are based on current customer's dependence, asappointedby Christensen(2006), particularly regarding MNCs from emerging countries.

The present paper is limited to subsidiaries of Brazilian MNCs acting in Portugal. In addition, only four companies were included. Although twelve interviews were conducted with intermediate managers from different areas which may provide a higher level of validity, the findings presented cannot be generalized to other subsidiaries of Brazilian companies. Future studies could look for sectors effects or countries context specific influences regarding where subsidiaries are located. Moreover, quantitative studies based upon large data bases with information on subsidiaries of Brazilian MNCs spread around the globe could further support the findings of the present study.

\section{References}

BARAÑANO, A. (2008). Métodos e técnicas de investigação em gestão: manual de apoio à realização de trabalhos de investigação. Lisboa, Edições Sílabo.

BARDIN, L. (2009). Análise de conteúdo. Lisboa, Edições 70.

BESSANT, J., \& TIDD, J. (2007). Innovation and Entrepreneurship. West Sussex, Chichester Wiley.

BIRKINSHAW, J. M., \& MORRISON, A. J. (1995). Configurations of strategy and structure in subsidiaries of multinational corporations. Journal of International Business Studies, 26(4), 729-754.

CAMUFFO, A., FURLAN, A., ROMYEAR, P., \& VINELLI, A. (2007). Routes towards supplier and production network internationalization. Journal of Operations and Production Management, 27(4), 37I - 387.

CHRISTENSEN, C. (2006). The Innovator's Dilemma. New York, Collins Business Essentials.

CHINI, T. (2004). Effective knowledge transfer in multinational corporation. New York, Polgrave-Macmillan.

COHEN, W. \& LEVINTHAL, D. (1990). Absorptive capacity: a new perspective on learning and innovation. Administrative Science Quarterly, 30, 128-I52.

COMPANY A. (2010). Fornecimentos: cada cliente uma história. Grupo A em revista, n. 57, march/april.

COMPANY B. (2008). Annual report 2008. Lisbon, Company B.

COMPANY D. (2010). Conheça a empresa: tecnologia e segurança. São Paulo, Company D. 
COSTA, C. G. (2006). Proximidade cultural e dinamismo econômico: por que investem as empresas portuguesas no Brasil. Revista de Administração de Empresas, 46, Edição Especial Minas Gerais.

CURADO, C. (2006). Organizational learning and Organizational design. The Learning Organization, 13 (I), 25-48.

DAFT, R. \& WEICK, K. E. (1984). Toward a model of organization as interpretation system. Academy of Management Review, 9(2), 284-295.

DESS, G., GUPTA, A., HENNART, J. \& HILL, C. (1995). Conducting and integrating strategy research at the international, corporate, and business levels: issues and directions. Journal of Management, 21 (3), 357-393.

EASTERBY-SMITH, M. \& PRIETO, I. (2008). Dynamic capabilities and knowledge management: a integrative role for learning? British Journal of Management, 19(3), 235-249.

FLEURY, A., \& FLEURY, M. T. L. (2007). Internacionalização de empresas brasileiras: em busca de uma abordagem teórica para os late movers. In: In Fleury, M. T. L. e Fleury, A. (Eds.) Internacionalização e os países emergentes. São Paulo, Atlas.

FORS, G. (1998). Location R\&D abroad: the role of adaptation and knowledge-seeking. In: BRAUNERHJELM, P. e EKHOLM, K. The geography of multinational firms. New York, Kluwer.

GRAY, C. (2006). Absorptive capacity, knowledge management and innovation in entrepreneurial small firms. International Journal of Entrepreneurial Behaviour \& Research, 12(06), 345-360.

GUILLEN, M., \& GARCIA-CANAL, E. (2009). The American model of the multinational firm and the "new" multinationals from emerging economies. Academy of Management Perspectives, 23(02), 23-35.

HONG, J. F. L., \& NGUYEN, T. V. (2009). Knowledge embeddedness and the transfer mechanisms in multinational corporations. Journal of World Business, $44,347-356$.
HSU, C., \& WANG, Y. S. (2008). A model o intraorganizational knowledge sharing: development and initial. Journal of Global Information Management, 16(3) 45-73.

JANTUNEN, A. (2005). Knowledge-processing capabilities and innovative performance: an empirical study. European Journal of Innovation Management, 8(3), 336-349.

LI, C. Y., \& HSIEH, C. Y. (2009). The impact of knowledge stickiness on knowledge transfer implementation, internalization, and satisfaction for multinational corporations. International Journal of Information Management, 29(6), 425-435.

MCCANN, B., \& FOLTA, T. (2008). Location matters: where we have been and where we might go in agglomeration research. Journal of Management, 34(3), 532-565.

NONAKA, I. (1991). The knowledge-creating company. Boston, Harvard Business Review.

PETERAF, M. (1993). The cornerstones of competitive advantage: a resource-based view. Strategic Management Journal, 14(3), |79-19I.

PORTER, M. Competitive strategy: techniques for analyzing industries and competitors by Michael Porter. In: Wheelen, T., \& Hunger, J. (2008). Strategic Management and Business Policy, IIth edition. New Jersey: Pearson / Prentice Hall.

KELLEY, T., \& LITTMANN, J. (200I). The art of innovation: lessons in creativity from IDEO, America's leading design firm. New York, Randon House.

OLIVEIRA JUNIOR, M. de M. (2007). Transferência de conhecimento e o papel das subsidiárias em corporações multinacionais brasileiras. In: Fleury, M. T. L.; Fleury, A. (Org.). Internacionalização e os países emergentes. São Paulo, Atlas, 216-237.

RIBEIRO, F. \& OLIVEIRA JR., M. (2009). Transferência e transferência reversa de conhecimento: o caso da aquisição da Perez Companc pela Petrobras na Argentina. Revista Brasileira de Gestão de Negócios, II(30), 79-93. 
RIEGE, A. (2007). Actions to overcome knowledge transfer barriers in MNC's. Journal of Knowledge Management, II(I), 48-67.

SHERER, F. L., GOMES, C. M., \& KRUGLIANSKAS, I. (2009). The internationalization process of Brazilian companies: a study of multiple cases in the heavy construction industry. Brazilian Administrative Review, 06(4), 280-298.

SUBSIDIARY B. (2008). Report "The company First Half 2008”. Lisbon, SB.

SUBSIDIARY B. (2008a). Report "Relatório de Gestão 2008". Brasília, MB.

SUBSIDIARY D. Institucional brochure "Perfil da empresa". Lisboa, SD, 2010.

THOMKE, S. \& HIPPEL, E. (2002). Customers as innovators: a new way to create value. Harvard Business Review, s/n, April, 74-8I.

URBAN, G. \& VON HIPPEL, E. (1988). Lead user analyses for the development of new industrial products. Management Science, 34(5), 569-82.

VERNON, R. \& WELLS, L. T. JR. (1991). The manager in the international economy, 6 e.d. New York: Prentice Hall.

VERNON, R. (1966). International investment and international trade in the product cycle. Quarterly Journal of Economics, 80(2), 190-207.

WANG, C. L., \& AHMED, P. K. (2007). Dynamic capabilities: a review and research agenda. International Journal of Management Reviews, 9(I), 3I-5I

WHEELEN, T., \& HUNGER, J. (2008). Strategic Management and Business Policy, Ilth edition. New Jersey: Pearson / Prentice Hall.

YANG, Q., MUDAMBI, R., \& MEYER, K. (2008). Conventional and reverse knowledge flows in multinational corporations. Journal of Management, 34(5), 882-992. 
J. Technol. Manag. Innov. 20II,Volume 6, Issue 4 